\title{
STUDIES ON FIVE SPECIES OF TENTHREDO LINNAEUS (HYMENOPTERA: TENTHREDINIDAE)
}

\author{
V. Vasu and M.S. Saini \\ Department of Zoology, Punjabi University, Patiala, Punjab 147002, India. \\ Email: saini20@glide.net.in
}

\begin{abstract}
Taxonomic studies on five species of Tenthredo Linnaeus were carried out of which two species are described and illustrated as new to science from the Indian subcontinent. The other three species, viz. Tenthredo occipitailis Malaise, Tenthredo salvizii (Malaise) and Tenthredo simlasensis (Cameron) are described and illustrated on a uniform systematic pattern. Key characters for Tenthredo maec sp. nov. include: ration of scape and pedicel as 5:3; post ocellar area broader than long as 5:4; antennal segment three and four as 4:3 and four apical antennal segments somewhat compressed. The specific characters of Tenthredo pleuriimpunctata sp. nov. are: frontal spot covering most of the frontal area but not touching eye margins; scape and pedicel as 5:3; antennal segment three and four as 3:2; mesosternum lacking thorns and post ocellar area almost quadrate.
\end{abstract}

KEYWORDS

Hymenoptera, New species, taxonomy, Tenthredinidae, Tenthredo maec sp. nov., Tenthredo pleuriimpunctata sp. nov.

\section{AbBreviations}

$E L=$ Eye length; IATS = Inner apical spur; ICD = Inter cenchri distance; IDMO = Interocular distance at level of median ocellus; ITD = Inter tegular distance; $L I D=$ Lower interocular distance; $M=$ Median cell; $M B=$ Metabasitarsus; OATS = Outer apical tibial spur; $O C L=$ Oculooccipital line; OLL = Oculoocellar line; $P O L=$ Postocellar line

Tenthredo Linnaeus is one of the largest genus of Tenthredinidae. More than 800 species have been reported all over the world so far, of which about 145 species are known from the Indian subcontient. Malaise (1945) was the first worker to compile the whole scattered work on the genus from South and Southeast Asia. Following his work, Muche (1982, 1983), Singh (1985), Singh et al. (1985), and, Singh and Saini (1987a, b, c, 1988a, b, c, d, 1994) added numerous new species to the Indian fauna of Tenthredo Linnaeus.

The present text deals with the detailed account of three already known species and also with the addition of two more new species to science from India. These species are described and illustrated on a uniform pattern suggested by Dr. D.R. Smith of USNM, Washington. Terminology used for description is after Ross (1937, 1945) and Malaise (1945). The type materials of the new species will be housed at the Division of Entomology, Pusa National Collection, Indian Agricltural Research Institute, New Delhi, India.

Among the members of subfamily Tenthredininae, species belonging to Tenthredo Linnaeus are characterised by a combination of characters: forewing with straight cross vein in the anal cell, hind wing with two closed $\mathrm{M}$ cell, clypeus emarginate, and propodeum with mid-longitudinal furrow dividing it into two equal parts.

\section{Tenthredo maec sp. nov.}

(Figs. 1-6)

\section{Material examined}

Holotype: One female, 20.vi.1991, Mukteswar, Uttar Pradesh, 2700m, coll. V. Vasu.

Paratypes: Two females, 20.vi.1991, Mukteswar, Uttar Pradesh, 2700m, coll. V. Vasu; one male, 10.v.1995, Toong, Sikkim, 1300m, coll. M.S. Saini; three females, four males, 15.v.1995, Phodong, Sikkim, 1700m, coll. M.S. Saini; one female, 12.v.1995, Gangtok, Sikkim, 1600m, coll. V. Vasu; four females, 20.v.1993, Dirang, Arunachal Pradesh, 1500m, coll. M.S. Saini.

\section{Etymology}

Species name is an arbitrary combination of letters derived from Mesoscutellar Appendage ECarinate.

\section{Distribution}

India: Arunachal Pradesh, Sikkim, Uttar Pradesh.

\section{Diagnostic features}

\section{Female}

Colour: Body pale yellow, black are: antenna, mandible apex, frontal spot (Fig. 2) anteriorly covering median fovea, medially connected with lateral spot not touching eye margin, posteriorly reaching hypothetical hind margin of head leaving postocellar area except anteromedial subtriangular spot and interocellar area; medial transverse stripe and medial spot on posterolateral margin of pronotum, spot on outer apex of tegula, mesonotal middle lobe except lateral margins; lateral lobe except inner deltoid spot and outer posterior margin of mesonotal lateral lobe; visible parts of metapostnotum, parapterum, stripe along suture of mesepisternum and mesepimeron; transverse deltoid spot on posterior margin along the border of mesosternum and mesepisternum; metepimeral suture; abdomen above (Fig. 3) except broad subrectagular medial spot on hind margin of each tergite narrowly confluenting with deflexed lateral side, entire tergite nine; posterior stripe on apical $1 / 2$ of profemur, entire protibia, posterior stripe on mesoleg except coxae, trochanter and basal $1 / 3$ of femur, posterior stripe only on metafemur, metatibia and tarsi entirely. Wings hyaline with infumated 
apices, venation including costa, subcosta and stigma fuscous to black.

Structure: Average length $11.5 \mathrm{~mm}$. Antenna subincrassate in middle, $1.8 \mathrm{x}$ head width, flagellum with apical four segments insignificantly compressed; scape and pedicel as 5:3, segments three and four as 4:3. Clypeus (Fig. 1) subrectangularly incised up to $1 / 5$ of its length; labrum (Fig. 1) broader than long as 5:4 with roundly pointed anterior margin; malar space $0.75 \mathrm{x}$ diameter of median ocellus. LID:IDMO:EL=1:2:2, POL:OCL:OOL= $1: 1.5: 1.8$. Frontal area below level of eyes, median fovea broad, canaliculate between supraantennal tubercles, not reaching median ocellus; supraantennal tubercles moderately raised, shallowly demarcated from low lying insignificant frontal ridges; postocellar furrow indistinct, inter and circumocellar furrows distinct; almost parallel; postocellar area subconvex, broader than long as $5: 4$; head narrowing behind eyes. ICD:ITD $=1: 3$; mesoscutellum roundly raised, its appendage ecarinate; mesepisternum with acute apex; mesosternum without thorns. Metabasitarsus equal to following three joints combined, metafemur as long as metatibia; tarsal claw with subapical tooth shorter than apical one; IATS: MB:OATS=1:1.5:0.75. Lancet (Fig. 6) having 32 serrulae.

Sculpture: Head shining with few, scattered, shallow punctation. Mesonotum with few, scattered, shallow punctation. Mesonotum shining with few, minute, distinct punctation; mesoscutellum with large, distinct, deep punctation on posterior slope, its appendage impunctate; mesepisternum impunctate; mesepisternum impunctate, shining; mesosternum punctate. Abdomen shining, microstriated with dense, minute, punctation.

Pubescence: Fuscous, 0.25x scape length.

\section{Male}

Average length $9 \mathrm{~mm}$. Similar to female except pale yellow in addition are: scape, tegula entirely, mesosternum entirely, broad posterior margins of propodeum and tergites 2-5; tergites 6-9 entirely ferruginous malar space linear. Genitalia: penis valve (Fig. 4), gonoforceps (Fig. 5).

\section{Individual variations}

Pale yellow colour of abdomen sometimes brownish-yellow.

\section{Remarks}

This new species can be compared with Tenthredo occipitalis Malaise but there are numerous points to distinguish these two as discussed under the latter. Some of the specific characters of this new species include: its unique colour pattern; ratio of scape and pedicel as 5:3; postocelar area broader than long as 5:4; antennal segments three and four as $4: 3$ and four apical antennal segments insignificantly compressed.

Tenthredo maec is widely distributed almost throughout the himalayan belt but its absence in the extreme east and extreme west of Himalaya is conspicuous as well strange. Mostly this species is confined to the low altitude areas (Mukeshwar is an exception) particularly in the northeastern states. In the field,
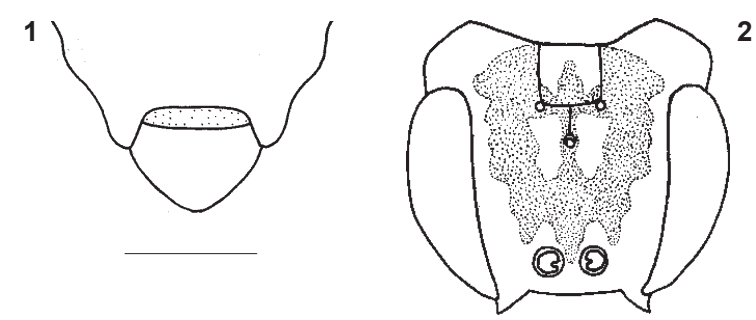

2
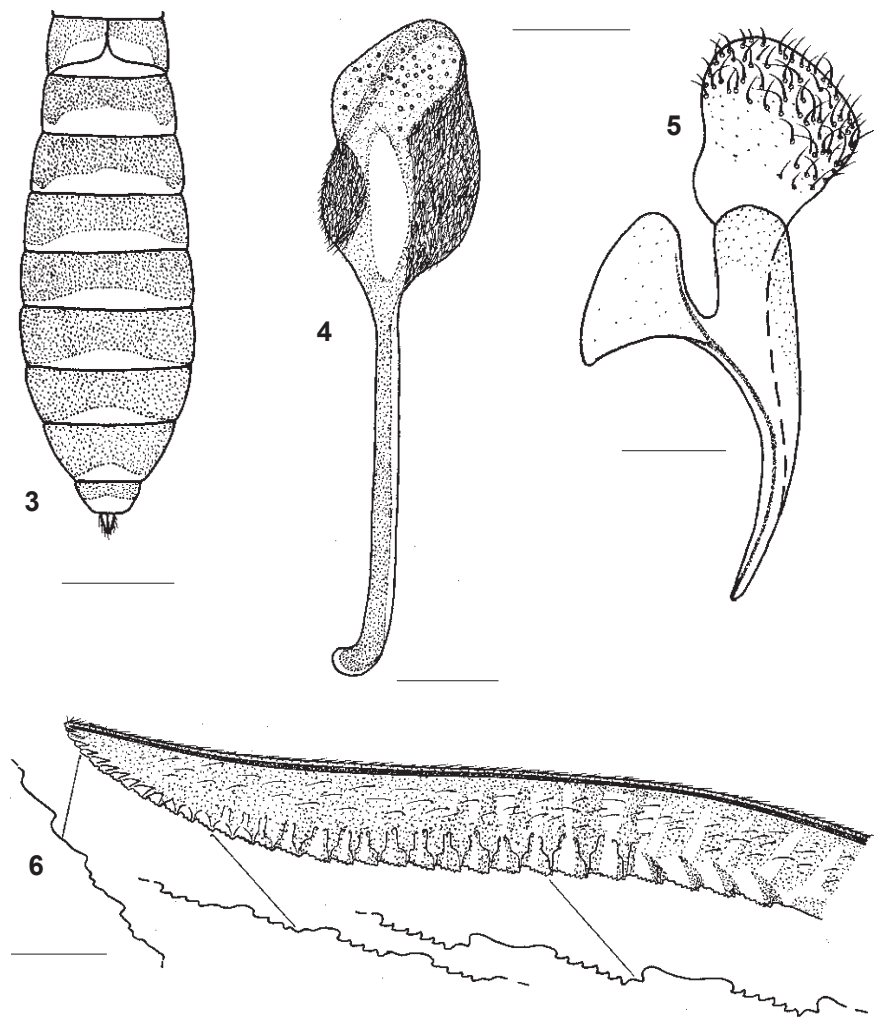

Figures 1-6. Tenthredo maec sp. nov. 1 - Clypeus and labrum; 2 - Colour pattern of head; 3 - Colour pattern of abdomen; 4 - Penis valve; 5 - Gonoforceps; 6 - Lancet. Scale $=1.0 \mathrm{~mm}$.

sometimes it is difficult to differentiate it from Tenthredo occipitalis and Tenthredo simlaensis but close examination reveals many outstanding differences. Generally there is a coexistence of all these species.

\section{Tenthredo pleuriimpunctata sp. nov.}

(Figs. 7-11)

\section{Materials examined}

Holotype: Female, 12.v.1995, Gangtok, Sikkim, 1600m, coll. V. Vasu.

Paratype: One male, 12.v.1995, Gangtok, Sikkim, 1600m, coll. M.S. Saini.

\section{Etymology}

Species name pertains to impunctate mesopleuron. 


\section{Diagnostic features \\ Female}

Colour: Body sordid yellow, black are: antenna, mandible apex; frontal spot (Fig. 8) covering most of frontal area, laterally not touching eye margin, posteriorly reaching hypothetical hind margin of head, anteriorly extending between supraantennal tubercles, excepting their anterior parts, posterior $1 / 2$ of frontal, ridges and spots on posterior margin of eye; median transverse stripe confluent with spot on dorsal angles of pronotum; mesonotal lateral and posterolateral margins; stripe along mesopleural suture, mesosternum, spot on posterior angle of metepimeron; lateral and anterior stripes on propodeum, tergites 2-8 barring narrow posterior margins. Legs reddish, black are: apical dot on posterior aspect of profemur, posterior stripe on apical $1 / 2$ of mesofemur, apical ring on mesotibia, posterior stripe on mesotarsi 1-4, apical $1 / 2$ of metafemur except ventral stripe, apical $1 / 3$ of metatibia, metatarsi entirely. Wings hyaline with yellowish tinge and subinfumated apices; venation including costa, subcosta and stigma fuscous to black.

Structure: Length $11.5 \mathrm{~mm}$. Antenna filiform, 1.9x head width, flagellum not compressed; scape and pedicel as 5:3, segments three and four as 3:2. Clypeus (Fig. 7) semi-circularly incised up to $1 / 3$ of its length with rounded lateral teeth; labrum (Fig. 7) broader than long as 4:3 with rounded anterior margin; malar space linear. LID:IDMO:EL=1:2.1:2.2; POL:OCL:OOL = 1:1.8:1.8. Frontal area below level of eyes, median fovea shallow, divided into anterior part having median longitudinal carina and posterior part with concave bottom and faintly indicated transverse ridge; low lying supraantennal tubercles confluencing with similar frontal ridges; post-and circumocellar furrows sunken, excurved (bulging), postocellar area convex, quadrate; head faintly narrowing behind eyes. ICD:ITD $=1: 3$, mesoscutellum subconvex, its appendage ecarinate, mesepisternum round, mesosternum lacking thorns. Metabasitarsus equal to following three joints combined, metafemur equal to metatibia, tarsal claw with subapical tooth shorter than apical one; IATS:MB:OATS=1:1.8:0.8. Lancet (Fig. 11) with 29 serrulae.

Sculpture: Head shining, almost impunctate. Mesonotum shining with scattered, fine, shallow punctation: mesoscutellum punctate like mesonotum, its appendage polished: mesepisternum almost impunctate, shining; mesosternum punctulate. Abdomen subshining, faintly microstriated, with dense, fine, shallow punctation.

Pubescence: Fuscous, 0.25x scape length.

\section{Male}

Length $10.5 \mathrm{~mm}$. Similar to female but additionally the following areas are sordid yellow: scape, postocellar area except broad anterior and narrow medial longitudinal stripe, broad sides of mesonotal middle lobe, mesosternum entirely, broad posterior $1 / 2$ of propodeum and tergite 2-5; tergites 6-3 with reddish tinge. Genitalia: penis valve (Fig. 9), gonoforceps (Fig. 10).

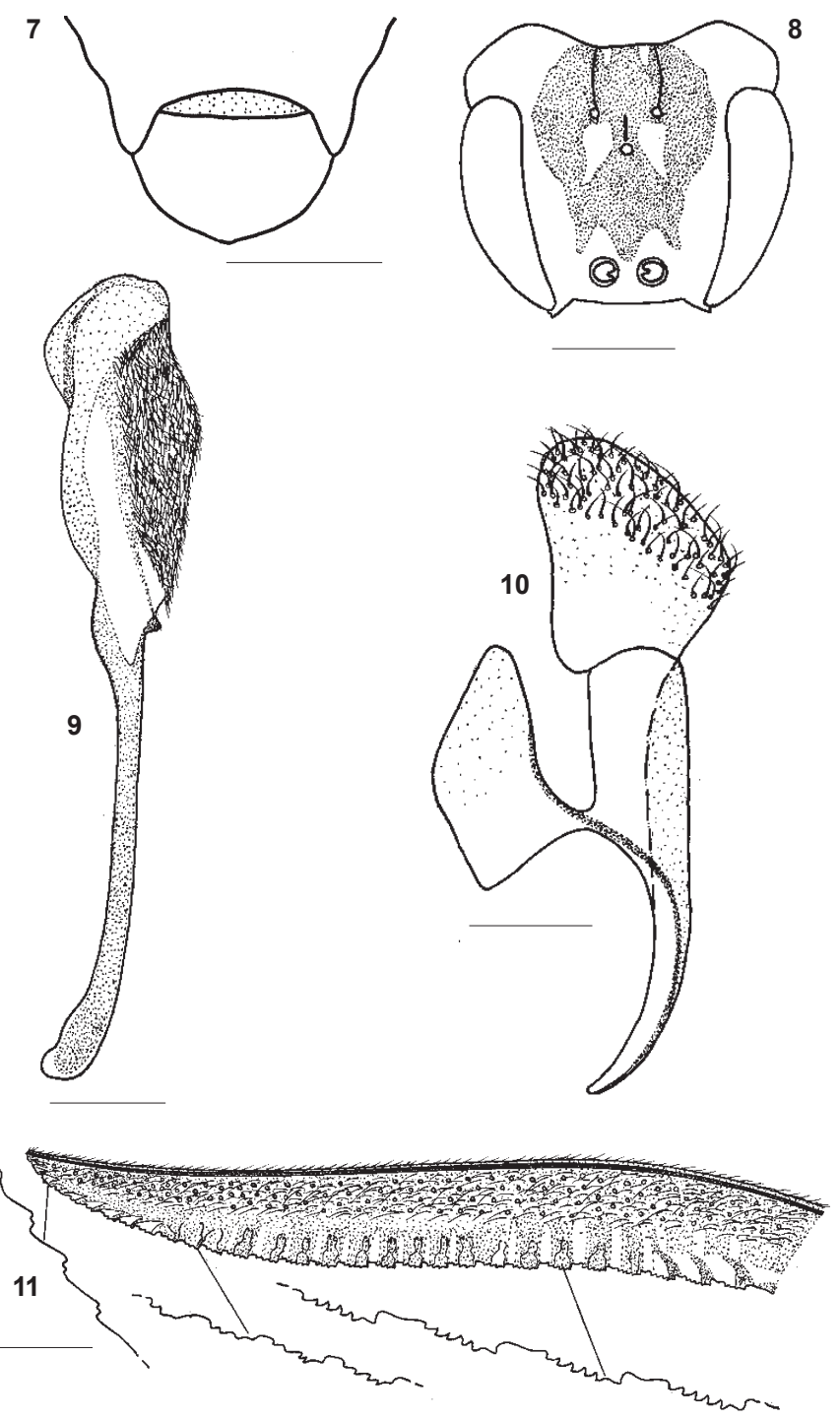

Figures 7-11. Tenthredo pleuriimpunctata sp. nov. 7 - Clypeus and labrum; 8 - Colour pattern of head; 9 - Penis valve; 10 - Gonoforceps; 11 - Lancet. Scale $=1.0 \mathrm{~mm}$.

\section{Discussion}

Collected from the slopes at the side of a river Gangtok (Sikkim) T. pleuriimpunctata is represented by two specimens only. The collection team surveyed this area for many days but no other specimen could be added. This shows that the species is rare in this area. The sides of Gangtok and near by areas are devoid of any good vegetation in May. After monsoon situation may be different. Though comparatively low lying polluted and devoid of any thick upper storey, yet river side of Gangtok harbours many unique species of saw flies confined to this area only. Even most of the Konow's type of Tenthredo were collected from this area.

As far as key characters are concerned, this species has similarities with Tenthredo simlaensis Cameron but can be easily separated from the latter, as discussed earlier. Some of the 
other prominent characters of this species include: frontal spot covering most of the frontal area but not touching eye margins; scape and pedicel as 5:3; antennal segments three and four as $3: 2$; mesosternum lacking thorns and postocellar area almost quadrate. In addition to all these, the overall colour pattern of this species is unique. This species was not observed during monsoon and post monsoon months.

\section{Tenthredo occipitalis Malaise}

(Figs. 12-18)

Tenthredo occipitalis Malaise, 1945: 234; Singh \& Saini, 1986: 78

\section{Materials examined}

Paratype borrowed from NR, Stockholm appended with labels as: Female Tenthredo occipitalis Malaise, Loan No. 587/96, N. E Burma, Kambaiti, 2200m, 1/6, R. Malaise.

Other specimens studied: One female, 23.vi.1985, Gobind Dham, 3000m, coll. D. Singh; one female, 21.vi.1991, Shyamkhet, Uttar Pradesh, 1900m, coll. M.S. Saini; one male, 22.vi.1991, Pangot, Uttar Pradesh, 2200m, Coll. M.S. Saini; one female, one male, 5.vi.1995, Gobind Ghat, Uttar Pradesh, coll. V. Vasu.

\section{Material depository}

Holotype and paratype at NR, Stockholm.

\section{Diagnostic features \\ Female}

Colour: Body pale yellow, black are: antenna, mandible tip, broad frontal spot (Fig. 13) anteriorly covering median fovea except supraantennal turbercles and convexity of frontal ridges lateral to median ocellus, laterally extending (without touching) to eye margin and posteriorly reaching hypothetical hind margin of head except narrow stripe inner to lateral furrows and a narrow stripe along upper $1 / 3$ of posterior eye margin; transverse medial stripe not reaching lateral margin and spot on dorsal angle of pronotum; mesonotum except stripe along side of middle lobe not reaching apex and two spots (one near apex of middle lobe and other lateral to mesoscutellum) on lateral lobe, narrow band along hind margin of mesoscutellum, metanotum except spot lateral to scutellum, hind margin of metapostnotum, parapterum, narrow stripe along each pleural suture, broken lateral stripe on mesosternum; abdomen (Fig. 15) above except broad subtriangular spot on posterior margin of each tergite; posterior stripe each along apical 2/3 of profemur, entire pro- and mesotibiae, and entire mesotarsi; tibiae and tarsi of metaleg entirely. Wings hyaline with yellowish tinge indistinctly infumated towards apex; venation including costa, subcosta and stigma fuscous.

Structure: Averge length $11 \mathrm{~mm}$. Antenna filiform, 1.9x head width, flagellum not compressed; scape and pedicel as $3: 2$, segments three and four as 3:2. Clypeus (Fig. 12) roundly incised with blunt lateral teeth; labrum (Fig.12) as long as broad with rounded anterior margin; malar space $0.6 \mathrm{x}$ diameter of median ocellus. LID: IDMO: EL = 1:1.9:1.7, POL:OCL:OOL =1:2:2. Frontal area below level of eyes; median fovea shallowly canaliculate, laterally limited by moderately raised supra- antennal tubercles confluencing more or less with low lying frontal ridges; post-, inter- and circumocellar furrows distinct; lateral furrows fine, slightly diverging posteriorly; postocellar area flat, broader than long as 6:5; head narrowing behind eyes. ICD:ITD $=1: 2.5$; mesoscutellum roundly raised, appendage faintly carinate; mesepisternum obtusely raised to acute apex; mesosternum lacking thorns. Metabasitarsus equal to following three joints combined; metafemur shorter than metatibia; tarsal claw (Fig. 10) with subapical tooth shorter than apical one; IATS:MB; OATS = 1:1.9: 0.8. Lancet (Fig. 18) having 28 serrulae.

Sculpture: Head shining with scattered, indistinct punctation. Mesonotum shining with few, distinct punctation; Mesoscutellum with few distinct punctation on posterior slope only, its appendage impunctate; mesepisternum with minute, indistinct punctation, having sebaceous lustre; mesosternum punctulate. Abdomen microstriated.

Pubescence: Fuscous, 0.25x scape length.

\section{Male}

Average length $10 \mathrm{~mm}$. Similar to female. Gentalia: penis valve (Fig. 16), gonoforceps (Fig. 17).

\section{Individual variations}

Posterior pale spots of tergites small subtriangular to large rectangular in shape.

\section{Distribution}

Burma, India: Uttar Pradesh.

\section{Remarks}

All the studied speciemens agree well with paratype borrowed from Stockholm. The male counter part of this species has been associated with its opposite sex for the first time.

Because of pyramidal and acutely elevated mesopleura $T$. occipitalis Malaise is shown as closely related to T. maec in the present text. However, both can be distinguished as follows: antenna is shorter than abdomen; postocellar area quadrate; antennal segment three and four as 3:2; frontal spot laterally touching upper eye margins and mesoscutellar appendage is carinate in T. occipitails, whereas, antenna is as long as abdomen, postocellar area broader than long, antennal segment three and four as $4: 3$, frontal black spot laterally not touching upper eye margins and mesoscutellar apendage is ecarinate in T. maec. In Malaise's (1945) key T. occipitalis has been keyed out against $T$. simlaensis. However, both can be differentiated as follows: in T. occipitalis mesopleura is quite smooth, polished and strongly shining; scutellum pyramidal, acutely elevated; postocellar area wider than long as 6:5 and mesepisternum raised into a thorn-like tip, whereas, in T. simlaensis mesopleura is with large, rugose and dense punctuation; scutellum is roundly raised; postocellar area wider than long as 2:1 and mesepisternum is only bluntly elevated.

In India, this species is so far found to be confined to the upper ranges of Garhwal and Kumaun Hills only. Almost similar set of 

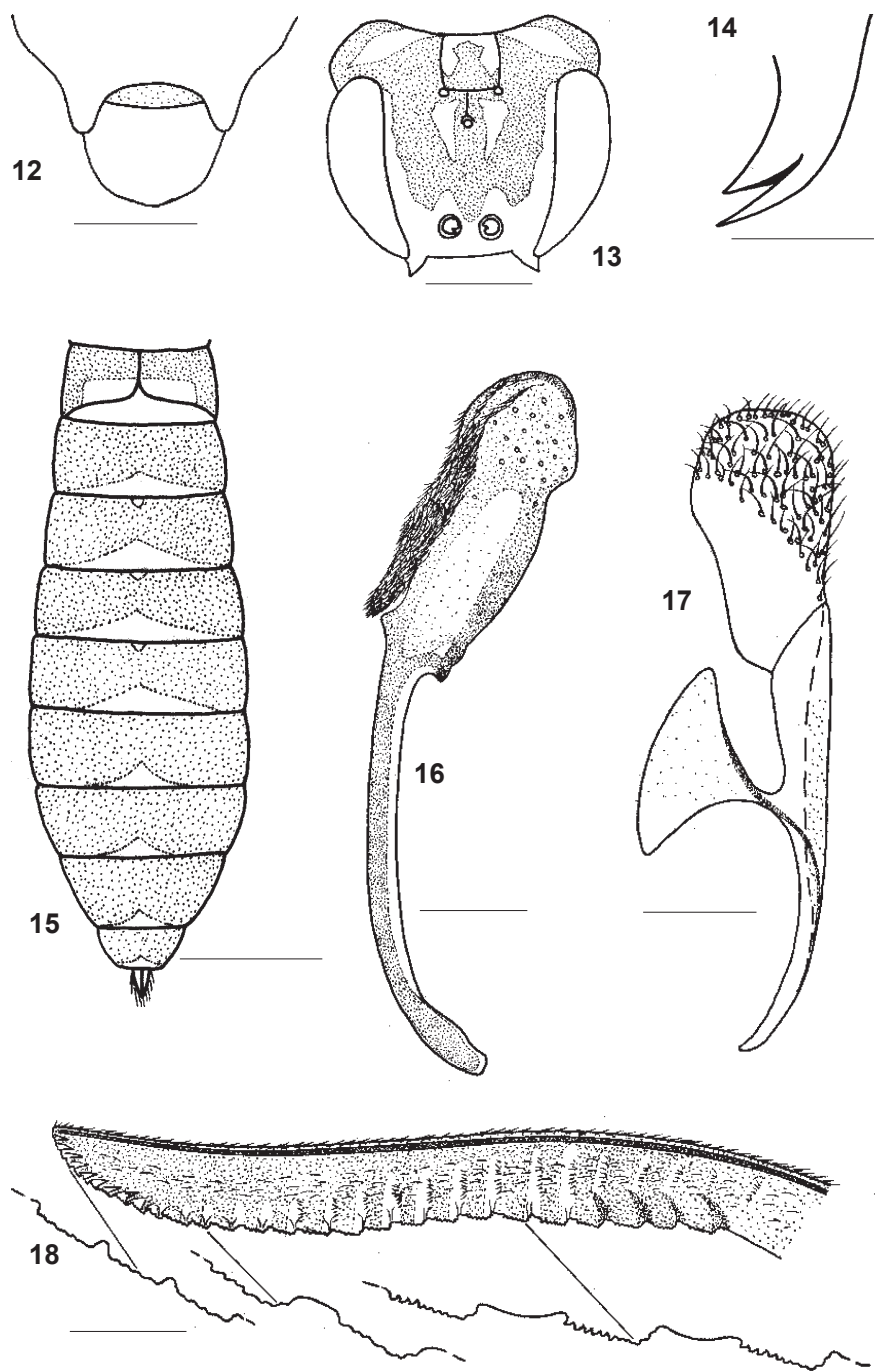

Figures 12-18. Tenthredo occipitalis 12 - Clypeus and labrum; 13 - Colour pattern of head; 14 - Tarsal claw; 15 - Colour pattern of abdomen; 16 - Penis valve; 17 - Gonoforceps; 18 - Lancet. Scale = 1.0mm.

ecological and topographical conditions have been seen at many places in India but this species is conspicuous by its adsence in all such areas.

\section{Tenthredo salvazii (Malaise)}

(Figs. 19-22)

Allantus salvazii: Malaise, 1934: 460.

Tenthredo salvazii: Malaise, 1945: 233; Singh \& Saini, 1986: 42.

\section{Material examined}

One female, one male, (borrowed from NR, Stockholm), labelled as: N.E. Burma. Kambaiti, 2200m, 20.v.1938, det. Malaise Other specimens studied: Five females, three males, 20.v.1989, Smit, Meghalaya, 1500m, coll. M.S. Saini.
Material depository

Holotype at NHM, London.

\section{Diagnostic features \\ Female}

Colour: Body black, whitish to sordid yellow are: mandible barring apex, labrum, clypeus, lower $2 / 3$ of hind orbit; dorsal and ventral angles and posterior slope of mesoscutellum, ridges lateral to meso- and metascutelli, anteromedial spot on metanotum, posterodorsal stripe on mesepimeron, broad irregular spot on mesepisternum along its border with sternum, metapleuron except stripe along pleural suture; deflexed lateral sides of all tergites, rectangular medial spot on tergite four, tergite nine entirely, all sternites; legs except bases of coxae and tarsi. Wings hyaline, stigma with pale base, venation including costa and subcosta fuscous.

Structure: Average length $8 \mathrm{~mm}$. Antenna stout, indistinctly incrassate towards apex, $1.4 \mathrm{x}$ head width, flagellum not compressed; scape and pedicel as 5:3, segments three and four as 9:5. Clypeus (Fig. 19) arcuately incised upto $1 / 4$ of its length with truncate lateral teeth; labrum (Fig. 19) broader than long as $4: 3$ with roundly pointed anterior margin, malar space $1 \mathrm{x}$ diameter of median ocellus. LID:IDMO: $E L=1: 1.8: 1.4$, POL:OCL:OOL $=1: 1 \cdot 2: 2.2$. Frontal area below level of eyes; median fovea just indicated with faint longitudinal carina supraantennal tubercles insignificant confluent with similar frontal ridges; post-, inter- and circumocellar furrows distinct, lateral furrows deep, diverging posteriorly; postocellar area subconvex with shallow median longitudinal furrow, broader than long as 7:4; head narrowing behind eye. ICD:ITD $=1: 3$, mesoscutellum subconvex, carinate; mesepisternum obtusely round, mesosternum lacking thorns. Metabasitarsus shorter than following three joints combined as 5:6, metafemur equal to metatibia; tarsal claw with subapical tooth shorter than apical one; IATS:MB:OATS =1:1.8:0.9. Lancet (Fig. 22) with 15 serrulae.

Sculpture: Head with dense, minute, distinct punctation, more prominent on frontal area. Mesonotum shallowly punctate with faint microsculpture; mesoscutellum with few, minute, punctation on anterior slope, densely punctate on posterior slope, its appendage punctate on lateral aspect only; mesepisternum densely and shallowly punctate with general oily lustre; mesosternum punctulate. Abdomen except propodeum and tergite two faintly microstriated with fine punctation.

\section{Pubescence: Silvery, $0.15 x$ scape length.}

\section{Male}

Average length $7 \mathrm{~mm}$. Similar to female except: spot on apical end of tegula black, mesoscutellum and appendage entirely black, whitish spot on mesosternum, propodeum and tergites 2-4 with pale posterior margins, rectanglular spot on tergite four faint. Genitalia: penis valve (Fig. 20), gonoforceps (Fig. 21). 


\section{Individual variations}

Minute whitish spot at tip of supraantennal tubercles, near upper eye corner, and lateral spot on appendage present.

\section{Distribution}

Myanmar; China; India: Himachal Pradesh, Meghalaya.

\section{Remarks}

Because of mesoscutellum being subconvex, and mesopleura raised, T. salvazii Malaise forms a distinct group of species which include $T$. simlaensis Cameron and $T$. pleuriimpunctata. However, it is distinct from the latter two in possessing densely punctate head and mesonotum and the mesoscutellum being longitudinally carinate. Head and mesonotum are almost impunctate and mesoscutellum ecarinate in $T$. simlaensis and T. pleuriimpunctata.

In Malaise's key T. salvazii has been keyed out against $T$. vittipleuris Malaise, a species collected from Burma (Kambaiti). However, both species are distinct due to some outstanding differences in the ratio of antennal joints three and four; punctation pattern of thorax; presence or absence of a longitudinal furrow on the postocellar area and colour pattern.

Malaise recorded this species from Simla (Himachal Pradesh) as well but we repeatedly visited this area without any success. We recorded this species from Smit, a tribal belt of Meghalaya. Smit has contributed many new species since it is almost cut off from the surrounding areas which are entirely under cultivation. Tribal populations of this area is very hostile, and hence local help is needed to visit the area. Because of large scale and uncontrolled deforestation, the total scenerio of this area is changing very fast. Intensive faunistic survey of the

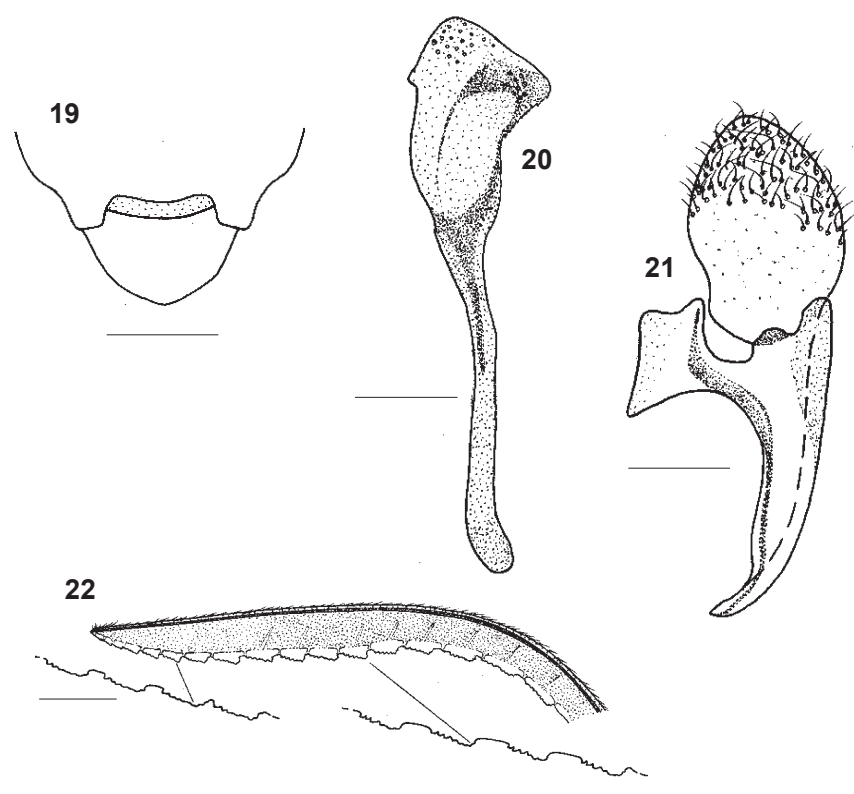

Figures 19-22. Tenthredo salvazii (Malaise) 19 - Clypeus and labrum; 20 - Penis valve; 21 Gonoforceps; 22 - Lancet. Scale $=1.0 \mathrm{~mm}$. area is urgently called for.

\section{Tenthredo simlaensis Cameron}

(Figs. 23-28)

Tenthredo simlaensis Cameron, 1899: 15; Konow, 1905: 143; Malaise, 1945: 234; Singh \& Saini, 1986: 42, 1987: 397; Tenthredo xanthopus Cameron, 1876: 467; Tenthredo ornatula new name for T. xanthopus : Enslin, 1920: 26

\section{Material examined}

15 Females, 12 males, 7.v.1985, Gangtok, Sikkim, 1600m, coll. D. Singh, 10 females, five males, 11.v.1985, coll. M.S. Saini; four females, three males, 13.v.1985, Mangan, Sikkim, 1300m, coll. M.S. Saini, seven females, 10 males, 15.v.1985, coll. M.S. Saini; three females, seven males, 4.v.1995, Singtam, Sikkim, 1000m, coll. V. Vasu; 20 females, 18 males, 9.v.1995, Rangrang, Sikkim, $1400 \mathrm{~m}$, coll. V. Vasu; two females, one male, Phodong, Sikkim, 1700m, coll. V. Vasu; 11 females, 10 males, 10.vi.1985, Mandal, Uttar Pradesh, 2400m, coll. D. Singh, eight females, six males, 13.vi.1985, coll. M.S. Saini, eight females, seven males, 17.vi.1985, coll. D. Singh.

\section{Material despository \\ Holotype of Tenthredo simlaensis Cameron at HEC, Oxford.}

\section{Distribution}

Burma; India: Himachal Pradesh, Uttar Pradesh, Sikkim.

\section{Diagnostic features \\ Female}

Colour: Body pale green, black are antenna, mandible tip, stripe along supraclypeal furrow; broad frontal spot (Fig. 24) covering median fovea leaving apical half of supraantennal tubercles, laterally reaching (without touching) eye margin, and posteriorly reaching hypothetical hind margin of head except stripe inner to lateral furrows; narrow stripe along hind margin of eye connected with frontal spot; pronotum except dorsal and ventral angles and posterior margin; mesonotum except sagittated apex of middle lobe and spot outer to mesoscutellum on lateral lobe, posterior slopes of scutelli, metanotum except spot lateral to scutellum, irregular anterior margin of metapostnotum, parapterum, narrow stripe along each pleural suture; mesosternum; anterior margin confluent with lateral spots on propodeum, large lateral spots on remaining tergites almost confluent in middle excepting row of pale triangles with apices directed backwards (Fig. 25); lateral stripe on metacoxa, frontal spot on meso- and metatrochanters; posterior stripe each along apical 1/4 of profemur, entire meso- and metafemora, entire front four tibiae and metatarsi; metatibia and tarsi entirely; tarsi of front four legs infuscated at apices. Wings dusky hyaline, forewing subinfumated towards apex, stigma brownish with greenish apical end, venation black.

Structure: Average length $12.5 \mathrm{~mm}$. Antenna incrassate before apex, $1.8 \mathrm{x}$ head width, flagellum not compressed, scape and pedicel as 2:1, segments three and four as 3:2; clypeus (Fig. 23) subrectangularly incised upto $1 / 8$ of its length; labrum (Fig. 23) broader than long as 5:4 with narrowly rounded anterior margin; 
malar space $0.6 \mathrm{x}$ diameter of median ocellus. LID:IDMO:EL=1: 2:1.9; POL:OCL:OOL=1:1.7:2.2. Frontal area below level of eyes; median fovea narrow with distinct longitudinal carina in anterior $1 / 2$, supraantennal tubercles moderately raised and confluencing with insignificant frontal ridges; post-, inter- and circumocellar furrows distinct, lateral furrows sharp, almost parallel; postocellar area subconvex with faint longitudinal carina, broader than long as $2: 1$; head narrowing behind eyes. ICD:ITD $=1: 2.5$; mesoscutellum round, raised, its appendage ecarinate; mesepisternum obtuse, mesosternum lacking thorns. Metabasitarsus shorter than following three joints combind as $8: 9$, metafemur shorter than metatibia, tarsal claw with subapical tooth shorter than apical one, IATS:MB:OATS=1:1.9:0.8. Lancet (Fig. 28) having 22 serrulae.

Sculpture: Head shining with scattered shallow punctation. Mesonotum polished with few, distinct punctation on middle lobe, mesoscutellum with some distinct punctation on posterior slope, its appendage impunctate; mesepisternum with distinct widely separated punctation along convexity; mesosternum finely punctate. Abdomen except impunctate propodeum faintly microsculptured

Pubescence: Mixed golden and fuscous, $0.15 x$ scape length.

\section{Male}

Average length $10.5 \mathrm{~mm}$. Similar to female except: scape and mesosternum pale green, proleg entirely pale green except spots near apical and basal ends of femur and tibia respectively; mesotrochanter without black, black spot of abdomen faint. Genitalia: penis valve (Fig. 26), gonoforceps (Fig. 27).

\section{Individual variations}

Meso- and metascutelli without black; black spot on abdomen replaced by light brownish spot, medial pale streak missing on tergites seven to eight, tergite nine entirerly pale to brown.

\section{Remarks}

All the specimens studied agree well with the descriptions by Cameron $(1876,1899)$ and smoothly fit in the key of Malaise (1945). While tracing synonymy, Malaise (1945) gave priority to Tenthredo simlaensis Cameron, 1899 over Tenthredo xanthopus Cameron, 1876, because the latter was preoccupied by a Japanese species.

In Malaise's key Tenthredo simlaensis keys near Tenthredo occipitalis but both can be easily set aside as discussed under Tenthredo occipitalis. However, in the present text, roundly raised mesopleura, nature of head and mesonotum almost impunctate and ecarinate mesoscutellum, brings this species close to Tenthredo pleuriimpunctata from which it can be separated by the following characters: In T. simlaensis mesopleura is with deep scattered punctation, clypeus is shallowly, circularly emarginate; mesonotal middle lobe is with pale sagitated apex and propodeum is with broad posteromesal margins, whereas in Tenthredo pleuriimpunctata mesopleura is impunctate; clypeus is deeply subrectangularly incised upto $1 / 3$ of its medial length; and narrow lateral margins of mesonotal
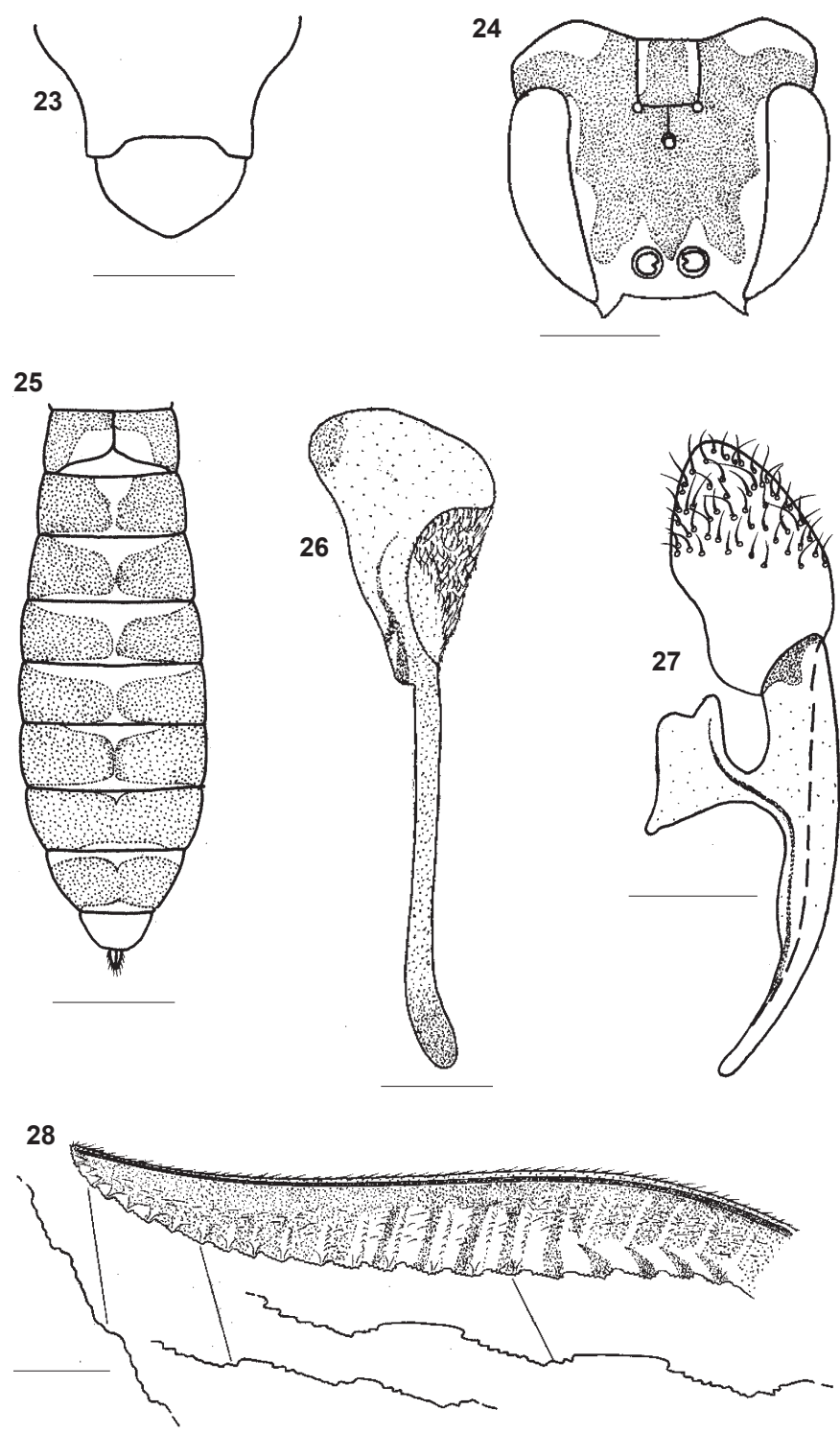

Figures 23-28. Tenthredo simlaensis Cameron 23 - Clypeus and labrum; 24 - Colour pattern of head; 25 - Colour pattern of abdomen; 26 - Penis valve; 27 - Gonoforceps; 28 - Lancet. Scale $=1.0 \mathrm{~mm}$.

middle lobe and narrow posteromesal margins of propodeum are pale.

Tenthredo simlaensis is widely distributed and abundantly available species adapted to varied set of ecological conditons. Broad shallow gorges, with constant flow of water and bushes of polygonum species are generally preferred by this species. It often indulges in zoophagy and competes with Robber flies.

\section{REFERENCES}

Malaise, R. (1934). On some sawflies (Hym.: Tenthre.) from Indian Museum, Calcutta. Records of the Indian Museum, Calcutta, 36: 453473.

Malaise, R. (1945). Tentherdinoidea of South-estern Asia with a general 
Zoogeographical review. Opusc. ent., Suppl., 4:1-288.

Muche, W.H. (1982). Beitrag zur Blattwespenfauna von Indian and Pakisthan mit Beschreibung einer neuen Art sowie Unterart (Hymenoptera, Symphyta, Tenthredinidae). Reichenbachia Mus. Tierk. Dresden, 20(15): 113-117.

Muche, W.H. (1983). Die Von Hern Dr. W. Wittmer in Indien and Bhutan gesammelten Blattwespen, mit Beschreibung von secks neuen Arten der Tenthredinidae (Hymenoptera, Symphyta. Reichenbachia Mus. Tierk. Dresden 21(29): 167-180.

Ross H.H. (1937). A generic classification of the Nearctic sawflies (Hymenoptera: Symphyta)-III. Biological Monograph 34: 1-173.

Ross, H.H. (1945). Sawfly of genitalia: Terminology and study techniques. Entomology News 56: 261-268.

Singh, B. (1985). Sawflies of genus Tenthredo Linn (Hymenoptera: Tenthredinidae) - Two new species from Himachal Pradesh, India. Annals of Biology 1(2): 179-183

Singh, B., S.S. Dhillon and T. Singh (1985). Three new species of the genus Tenthredo Linn (Tenthredinidae: Hymenoptera) from India. Entomon 10(3): 203-207.

Singh B., T. Singh and S.S. Dhillon (1985). Two new species of genus Tenthredo Linn (Hymenoptera: Tenthredinidae) from NorthWest Himalaya, India. Uttar Pradesh Journal of Zoology 5(1): 37-41. Singh, D. and M.S. Saini (1986). Zoogeographical distribution of genus Tenthredo Linn Hymenoptera: Tenthredinidae) in India. Annals of Entomology 42(2): 41-44.

Singh, D. and M.S. Saini (1987a). Six new species of Tenthredo Linn from North-western India (Hymenoptera, Symphyta, Tenthredinidae). Reichenbachia Mus. Tierk. Dresden 24(29): 189-198.

Singh, D. and M.S. Saini (1987b). Six new species of Tenthredo Linn (Hymenoptera: Tenthredinidae) from India. Journal of New York Entomological Society 95(2): 328-337.

Singh, D. and M.S. Saini (1987c). Five new species of Tenthredo Linn. from Uttarkhand area (India) (Hymenoptera: Tenthredinidae). Dtsch. ent. Z., 34(4-5): 397-405.

Singh, D. and M.S. Saini (1988a). Five new species of Tenthredo Linn. (Hymenoptera: Tenthredinidae) from the Garhwal Hills. Journal of the Bombay Natural History Society 85(1): 143-150

Singh, D. and M.S. Saini (1987b). Six new species of Tenthredo Linn. from the Western Himalaya (Insecta, Hymenoptera, Symphyta, Tenthredinidae). Reichenbachia Mus. Tierk. Dresden 25(22): 137-147. Singh, D. and M.S. Saini (1987c). Six new species of Tenthredo Linn. from (Hymenoptera: Tenthredinidae) from Northern India Journal of the Bombay Natural History Society 85(2): 366-375.

Singh, D. and M.S. Saini (1987d). Five new species of Tenthredo Linn. from the Eastern Himalaya (Hymenoptera, Tenthredinidae). Dtsch. ent. Z., 35(4-5): 387-394.

Singh, D. and M.S. Saini (1994). Two new species of genus Tenthredo Linn. (Hymenoptera: Tenthredinidae) from Northern Himalaya. Uttar Pradesh Journal of Zoology 14(2): 129-133.

\section{ACKNOWLedGements}

The authors are highly thankful to Dr. D.R. Smith of USNM, Washington for his valuable suggestions. Financial assistance rendered by USDA, Washington in coordination with ICAR, New Delhi is acknowledged with thankfulness.

\section{A NOTE ON MOCK-MATING BEHAVIOUR IN DAMSELFLIES (ODONATA: INSECTA)}

\author{
Muhamed Jafer Palot and C. Radhakrishnan
}

Zoological Survey of India, Western Ghats Field Research Station, Kozhikode, Kerala 673002, India.

During our ecological studies in Madayipara, a laterite hillock situated about $21 \mathrm{~km}$ north of Kannur Town in Kerala, we observed an unusual mating behaviour exhibited by two species of damselflies near a pond. The aquatic as well as marginal vegetation in and around the pond provided good foraging and perching sites for many odonates.

On 6 September 2001, we observed a swarm of Copera marginipes (Rambur) and Ceriagrion cerinorubellum (Brauer) around the pond. At about $0815 \mathrm{hr}$, a male $C$. marginipes was found flying in tandem with a female $C$. cerinoubellum. After perching on the tip of a grass blade, the male $C$. marginipes extended its abdomen towards the neck region of the female $C$. cerinorubellum. While clasping, the female attempted to form the wheel position by bending its abdomen towards the genital organ of the male situated on the second segment of its abdomen. Even after great efforts, the female damselfly could not place her genital part perfectly in position to effect mating, though they remained in the wheel position for about 40 minutes before freeing themselves. On their separation, we collected the pair and identified them as the male of Copera marginipes (Rambur) (Family: Platycnemididae) and the female of Ceriagrion cerinorubellum (Brauer) (Family: Coenagrionidae).

Corbet (1983) states that male odonates occasionally grasp females of species other than their own, but in such cases the female do not co-operate by bending the abdomen forward in to the copulatory position and that they attempt to free themselves. On the countrary, in our observation the female did co-operate by bending the abdomen forward and remained in the wheel position for a considerable period of time though never succeeded in mating. Our observation is in conformity with that of Neville (1959) in which inter-generic mating attempts by female co-operation do occur occasionally in mixed pairs of odonates.

\section{REFERENCES}

Corbet, P.S. (1983). A Biology of Dragonflies. E.W. Classey Ltd., Oxon. 247pp.

Neville, A.C. (1959). Inter-generic pairing in Odonata. Entomology Monthly Magazine 95: 179.

\section{ACKnowledgement}

The authors are grateful to the Director, Zoological Survey of India, Kolkata for facilities and encouragement. 